\title{
Argumentação do Diabo
}

\author{
The Devil's Argument
}

\section{Jean Pierre Chauvin}

Doutor em Letras (Teoria Literária e Literatura Comparada Professor Escola de Comunicações e Artes da Universidade de São Paulo tupiano@usp.br

Resumo: No Evangelho Segundo Jesus Cristo (1991), José Saramago questiona os juízos de Deus e a autoridade divina, transferindo maior coerência para Jesus e Diabo. Para isso, o romancista parodia narrativas bíblicas, ressalta o caráter moral da religião e emprega variações na linguagem, o que sugere questionar os limites da representação literária.

Palavras-chave: José Saramago; Ficção; História; Religião.

\begin{abstract}
In The Gospel According to Jesus Christ (1991), José Saramago puts in regard the judgments of God, also the divine authority, transferring greater coherence to Jesus and the Devil. For this, the novelist parodies biblical narratives, emphasizes the moral character of religion and uses some variations in language, which suggests questioning of the limits of literary representation.

Keywords: José Saramago; Fiction; History; Religion.
\end{abstract}


“- Nada acontece sem a permissão de Deus - e Deus é a própria bondade. Logo, tudo o que acontece é o melhor" (Jean-Paul Sartre). ${ }^{1}$

"Então o Diabo disse, É preciso ser-se Deus para gostar tanto de sangue" (José Saramago $)^{2}$

"O cara mais underground que eu conheço é o diabo" (Zeca Baleiro $)^{3}$

\section{In Nomine Pater}

É sobremodo conhecida do público leitor a polêmica que cercou a publicação de O Evangelho Segundo Jesus Cristo, em 1991. Graças à censura moral e política que o livro suportou em Portugal (a obra não pôde concorrer a um prêmio literário no exterior), José Saramago mudou-se para a ilha de Lanzarote ${ }^{4}$, nas Canárias, dois anos depois, e de lá raramente saiu. ${ }^{5}$

No que diz respeito ao enredo de $O$ Evangelho, supondo que o seu livro esteja a salvo de eventuais melindres de ordem moral ou metafísica, o volume também poderia ser intitulado "Evangelho do Diabo" - sem prejuízo do que nele vai escrito, tampouco da importância conferida às personagens de que o enredo se nutre e compõe.

O episódio mais célebre (não necessariamente o mais polêmico) está no capítulo vinte e dois. Caminhamos para o epílogo. Jesus Cristo levantara-se cedo para pescar com os companheiros, mas os homens se deparam com uma névoa incomum, que lhes impedia a visão de maior alcance e de conduzir o seu trabalho - ocasião em que seriam amparados por novos milagres a cargo de Jesus Cristo.

A lida diária dos pescadores é interrompida; e o filho de Deus, que além de operar maravilhas, possui o dom da exegese demiúrgica e de alguma retórica, interpreta aquele

1 O Diabo e o Bom Deus, 1973: 22.

2 O Evangelho Segundo Jesus Cristo, 2000: 391.

3 “Heavy Metal do Senhor” [Por Onde Andará Stephen Fry?] (2013).

4 "Lembrei-me então de um poema do poeta brasileiro Ribeiro Couto, lido há muitos e muitos anos, e que a memória, vá lá saber-se porquê, guardou o poema que começa com estas palavras: 'Chove. Quando chove é que bom tempo’. Não precisam dizer-me que não é assim em todos os lugares, mas em Lanzarote só o pode saber verdadeiramente quem cá vive" (SARAMAGO, 1999: 26).

5 "O biógrafo de Saramago, Fernando Gómez Aguilera, explicou hoje à Agência Efe que o escritor português se refugiou na ilha dos vulcões em 1993, após abandonar Portugal pela falta de apoio que teve seu Evangelho segundo Jesus Cristo e lembrou que escreveu depois em sua casa de Tías o Ensaio sobre a Cegueira" (SARAMAGO, 2010: s/p). O veto partiu de António da Costa de Albuquerque de Sousa Lara à época, Subsecretário de Estado da Cultura do Governo Cavaco Silva (SEPÚLVEDA, 1992). A polêmica resultou em sua demissão do cargo. 
silêncio branco e profundo ${ }^{6}$ como sinal para um diálogo esclarecedor que, por sinal, há muito tardava e logo se efetiva:

Este é o Diabo, de quem falávamos há pouco. Jesus olhou para um, olhou para outro, e viu que, tirando as barbas de Deus, eram como gémeos ${ }^{7}$, é certo que o Diabo parecia mais novo, menos enrugado, mas seria uma ilusão dos olhos ou um engano por ele induzido. Disse Jesus, Sei que é, vivi quatro anos na sua companhia, quando se chamava Pastor, e Deus respondeu, Tinhas de viver com alguém, comigo não era possível, com a tua família não querias, só restava o Diabo (SARAMAGO, 2000: 368).

Há relativa formalidade por parte de Deus, em seu discurso de cunho didático, o que reforça o teor irônico do diálogo e da situação. Em seu apelo teatral, a cena se torna ainda mais risível, graças ao tom debochado que somente a voz celestial parece ser capaz. A aparente vitória do Senhor é corroborada pela postura quase humilde de Diabo. Resta saber se ele pouco disse por temer a Deus ou se por julgar, de antemão, que a sua refutação não surtiria maior efeito. Em análise atenta, Vera Bastazin (2006: 56) constatou que:

O evangelho poético de Saramago é [...] uma obra de características diferenciadas em relação a qualquer outra. Considerada a palavra enquanto objeto textual de qualquer dos evangelhos [...], notar-se-á que sua performance, no caso do romance, ultrapassa possíveis enfoques religiosos e se realiza num contexto outro, no qual ela é responsável pela ação crítico-metalinguística, entretecida no enredamento poético da obra.

A despeito dos argumentos e refutações, altercados entre Deus, Jesus e Diabo (todos, aqui, sem artigo definido, a bem da simetria semântica, sintática e providencial), não será este o episódio em que a oratória demoníaca ganha em força ou consistência. Em verdade, diga-se que a presença física Dele - metamorfoseado em Mendigo, Anjo ou Pastor - antecede o nascimento de Jesus Cristo.

6 Haveria relação entre o intenso nevoeiro do Evangelho com a cegueira branca de Ensaio sobre a Cegueira, publicado em 1995? Ambas as condições envolvem o questionamento dos poderes (religioso, político ou militar) e supõem a incapacidade dos homens para exercer a solidariedade.

7 Neste trabalho, as transcrições dos romances respeitam a grafia do escritor. 
A argumentação do diabo se faz no transcorrer da narrativa. É o Senhor das Trevas que, no plano terrestre, acompanha de perto o menino até se tornar homem e que, no final, serve como seu advogado de defesa frente aos desígnios e meios operados por Deus - em sua conduta reta e rigorosamente fiel aos próprios planos. Deus é sobremodo poderoso: em seus desígnios, o Senhor envolveu tanto o Diabo, já expulso dos Céus, quanto o Messias, que logo regressará às nuvens metafóricas:

Não criei nenhum mundo, não posso avaliar, disse Jesus, Pois é, não podes avaliar, mas ajudar, podes, Ajudar a quê, A alargar a minha influência, a ser deus de muito mais gente, Não percebo, Se cumprires bem o teu papel, isto é, o papel que te reservei no meu plano, estou certíssimo de que em pouco mais de meia dúzia de séculos, embora tendo de lutar, eu e tu, com muitas contrariedades, passarei de deus dos hebreus a deus dos que chamaremos católicos, à grega, E qual foi o papel que me destinaste no teu plano, $\mathrm{O}$ de mártir, meu filho, o de vítima, que é o que de melhor há para fazer espalhar uma crença e afervorar uma fé (SARAMAGO, 2000: 370).

Instalado no leito do mar, o tribunal divino está suficientemente protegido da interferência dos homens, que ficaram à margem (física e simbólica). O isolamento físico das entidades e de Jesus assegura a presença de Deus e, vantagem extra, retarda a vinda do Demônio - que, no romance, chega a nado, com aparente dificuldade.

Deus vence, em termos de solenidade, mas a persuasão de Diabo é de outra sorte: advém de outra parte e começa bem antes do célebre diálogo na embarcação providencialmente longe dos homens, em meio ao nevoeiro, e acima dos peixes. Lembrese que a retórica diabólica já durava décadas: o Senhor das Trevas mantinha contato relativamente assíduo com Maria: submissa e cumpridora esposa do carpinteiro José. Demônio dera o ar de sua graça em diversas ocasiões, a começar como Pedinte/Anjo, subvertendo a versão bíblica do Arcanjo Gabriel:

Maria segurava a escudela no côncavo das duas mãos, taça sobre taça, como quem esperava que o mendigo lhe depositasse algo dentro, e ele sem explicação assim fez, que se baixou até ao chão e tomou um punhado de terra, e depois erguendo a mão deixou-a escorregar lentamente por entre os dedos, enquanto dizia em surda e ressonante 
voz, O barro ao barro, o pó ao pó, a terra à terra, nada começa que não tenha de acabar, tudo o que começa nasce do que acabou. Turbou-se Maria e perguntou, Isso que quer dizer, e o mendigo respondeu apenas, Mulher, tens um filho na barriga, e esse é o único destino dos homens, começar e acabar, acabar e começar [...] E tu quem és, para não teres precisado de ouvi-lo da minha boca, Sou um anjo, mas não o digas a ninguém (SARAMAGO, 2000: 33).

Na noite em que nascia o primogênito de José e Maria, Diabo volta a se manifestar, dessa vez na pele de Pastor, levando um singelo presente ao recém-nascido. Três homens humildes e oriundos do campo tomam o lugar dos pomposos Reis Magos, figurados nas Escrituras. Em lugar de mirra, ouro e incenso, os pastores de Saramago trazem gêneros de maior serventia:

O primeiro pastor avançou e disse, Com estas minhas mãos mungi as minhas ovelhas e recolhi o leite delas. Maria, abrindo os olhos sorriu. Adiantou-se o segundo pastor e disse, por sua vez, Com estas minhas mãos trabalhei o leite e fabriquei o queijo. Maria acenou com a cabeça e voltou a sorrir. Então, o terceiro pastor chegou-se para diante, num momento pareceu que enchia a cova com a sua grande estatura, e disse, mas não olhava nem o pai nem a mãe da criança nascida, Com estas minhas mãos amassei este pão que te trago, com o fogo que só dentro da terra há o cozi. E Maria soube quem ele era (SARAMAGO, 2000: 84).

Obra de contestação, de transgressão, o romance recorda o aspecto simbólico dos evangelhos e concede ao nascimento de Jesus maior verossimilhança, humanidade e coerência que a palavra sagrada. Antes de tomar distância de Maria, (o) Diabo reaparece, ainda uma vez, na forma de Anjo e relembra o pecado mortal que atormentará José:

[...] vim só para dizer-te que não voltarás a ver-me tão cedo, tudo o que era necessário que acontecesse aconteceu, faltavam estas mortes, faltava, antes delas, o crime de José. Disse Maria, O crime de José, meu marido não cometeu nenhum crime, é um homem bom. Disse o anjo, Um homem bom que cometeu um crime, não imaginas quantos antes dele os cometeram também (SARAMAGO, 2000: 115). 
A morte do pai terrestre de Jesus é emblemática: acontece na cruz, com a mesma idade com que o seu primogênito seria igualmente crucificado, duas décadas depois: "O carpinteiro, chamado José filho de Heli, era um homem novo, na flor da vida, fizera há poucos dias trinta e três anos" (SARAMAGO, 2000: 166). Dias após o inexplicável desparecimento do homem, Jesus e Maria partem em seu encalço, até que topam com o seu corpo, vergado da cruz e em decomposição.

Ao se despedir da mãe, o filho dirige-se àquele que reconhece como pai primeiro e físico: "Jesus, de joelhos gritou, e todo o seu corpo lhe ardia como se estivesse a suar sangue, Pai, meu pai, por que abandonaste" - cena dramática que se passa sob os olhos de Pastor, "De longe, sentado no meio das ovelhas e confundido com elas" (SARAMAGO, 2000: 189).

O Evangelho segundo Jesus Cristo envolve, portanto, triplo problema de paternidade. Concebido por Maria e José, o jovem aprende a pensar e a trabalhar com Diabo e, afinal, percebe seu modesto lugar, na máquina divina, em relação a Deus terceiro pai, mas o de maior poder e alcance. Quem diz paternidade, diz poder. O Senhor é árbitro dos destinos alheios e, não por acaso, governa o discurso, o barco e a vida do filho/mártir. Como percebeu José Carlos Barcellos, é a ambição de um Deus, desejoso de ampliar os horizontes da Igreja, que se manifesta nos diálogos e ações que perpetra. As constantes mostras de seu poderio residiriam numa:

[...] particular perspectivação da história de Jesus, que enforma todo o Evangelho de Saramago, denuncia um a priori hermenêutico que poderíamos chamar de "a lógica do poder": o Deus do romance está insatisfeito por ser apenas o Deus dos judeus e quer expandir seu próprio culto e domínio a toda a humanidade, quer se tornar precisamente o Deus dos católicos, e, para tanto, encontra na culpa e na necessidade de sua expiação um elemento universal, capaz de ser utilizado como instrumento eficaz na obtenção de semelhante propósito. Deus, personagem do romance, é um grande estrategista, um fino conhecedor e hábil manipulador da psicologia social, um verdadeiro modelo para todos os ditadores e demagogos de ontem e de hoje (BARCELLOS, 2003: 151). 
A trajetória de Jesus Cristo teria sido tramada por Deus, alfa e ômega, em cumplicidade com Diabo? A estruturação do romance e o encontro no mar - curso d'água, encruzilhada discursiva - sugere que sim. Fruto de decisões ou das contingências, o percurso do filho tripartite oscila entre os dois solos onde vivera (Nazaré e Belém); divide-se entre a casa de Madalena (aquela que optou por deixar de ser o que fora) e o mar; alterna-se entre o trabalho de pescador e o de semeador das palavras preordenadas pelos céus.

O fato é que as idas e vindas do menino Jesus coincidem com as mudanças nas nuvens e as movimentações sob a terra. Assim que Jesus deixa a casa de Maria e seus irmãos, em Nazaré, o Anjo volta a aparecer à mãe, contrastando com a claridade lunar, realçando e realçado pela limpidez da noite:

Um vulto alto e negro movia-se lentamente, avançava em direcção à porta, e Maria, mal o viu, levou as mãos à boca para não gritar. Não era o filho, era, enorme, gigantesco, imenso, o mendigo, coberto de farrapos como da primeira vez e também como da primeira vez, agora quiçá por efeito do luar, subitamente vestido de trajes sumptuosos que um sopro poderoso agitava (SARAMAGO, 2000: 195).

Entre dúvidas e certezas, Jesus cresce física, espiritual e intelectualmente. De pequenino visitante de sinagogas, passa a menino, depois a jovem questionador. Mais tarde, quando Cristo já está em idade de correr mundo e trabalhar, Pastor fará dele o seu ajudante a zelar pelas ovelhas, recorde-se, a pedido do próprio rapaz. A decisão do jovem não está revestida de misticismo ou benevolência: envolve a necessidade de prover a si mesmo, através do trabalho. Isolado do mundo, Jesus recebe a visita de Pastor na mesma gruta onde nascera. Após breve discussão, Cristo detecta a sabedoria e a lógica do homem e lhe pede guarida:

Que nome é o teu, Para as minhas ovelhas não tenho nome, Não sou uma ovelha tua, Quem sabe, Diz-me como te chamas, Se fazes tanta questão de dar-me um nome, chama-me Pastor, é o suficiente para que me tenhas, se me chamares, Queres levar-me contigo, de ajudante, Estava à espera que mo pedisses, E então, Recebo-te no meu rebanho (SARAMAGO, 2000: 227). 
O que as dúvidas do filho de Deus sugerem? Que, forjado como humano, padece com as mesmas paixões que nós, mais mortais e limítrofes que ele. Fernando Segolin (1999: 14) notara que:

A escritura de Saramago é exatamente essa festa deslocadora, destronadora, empenhada em arrancar nossas certezas e pseudoverdades dos pedestais sólidos em que foram assentadas e pô-las em cena num palco girante com o intuito de despi-las de sua monovalência [...] Como evangelista, Saramago não se propõe apenas a contar/recontar a história do nascimento, vida, paixão e morte de Cristo, e sim tecer um tex to coreográfico, feito do encontro/desencontro de fragmentos textuais recolhidos da Bíblia, dos evangelhos canônicos, dos evangelhos apócrifos, da história da Palestina dos primeiros setenta anos de nossa era, de Camões, de Fernando Pessoa, bem como da releitura e alusões referentes a obras pictóricas [...]

A relação entre Jesus e Diabo perdurava havia anos, quando Deus finalmente intervém a semear a discórdia e separá-los. Recorde-se que a ruptura entre Pastor e Jesus envolve questão anterior, relacionada à recusa de Cristo em sacrificar uma ovelha, determinada pelo Senhor. Cedendo, não ao argumento divino, mas ao poder explicitado por Deus, dessa feita o rapaz sacrifica o animal (gesto simbólico que reafirma a potência celestial). Em seguida, o jovem retorna ao rebanho liderado por Pastor:

Quando Jesus chegou ao campo, Pastor olhou-o fixamente e perguntou, A ovelha, e ele respondeu, Encontrei Deus, Não te perguntei se encontraste Deus, perguntei-te se achaste a ovelha, Sacrifiquei-a, Por quê, Deus estava lá, teve de ser. Com a ponta do cajado, Pastor fez um risco no chão, fundo como rego de arado, intransponível como uma vala de fogo, depois disse, Não aprendeste nada, Vai (SARAMAGO, 2000: 264-5).

Jesus passara a infância em companhia do pai biológico; durante quatro anos, convivera com Demônio; os restantes, a carregar o capricho de Deus, que tinha em vista a expansão das lutas em nome da fé. Mas o reinado do Senhor não será de todo tranquilo. Em breve, Cristo passaria das mãos do Demônio para as mãos de uma mulher que ele 
contemplara a sair do mar. Suas companhias na terra aprimoram a capacidade de questionar os desígnios celestiais e a religião encarregado de representar.

Como prescreve o Gênesis, a linha reta do homem escolhido por Deus é desviada pela tentação da carne ${ }^{8}$. Jesus Cristo é homem quase feito, quando conhece Maria de Magdala - prostituta que deixa de sê-lo para viver exclusivamente em sua companhia. Contrapondo-se ao senso comum ${ }^{9} \mathrm{e}$ à ideologia dos bons costumes, o narrador descreve Madalena de maneira a positivar a sensualidade feminina. Após cuidar do ferimento nos pés de Jesus, o que evoca o mito em torno das feiticeiras ${ }^{10}$, ela desperta o desejo do homem e tem início o seu enlace amoroso.

Saliente-se que, ao enfatizar a naturalidade do encontro sexual entre ela e o rapaz, o narrador desqualifica o estereótipo de mulher lasciva e adúltera, conjugando afeição e desejo, alma e carne, mundanice e sacralidade ${ }^{11}$.

A mulher reapareceu com um pequeno boião e vinha a sorrir como se alguém, dentro de casa, lhe tivesse contado uma história divertida. Jesus via-a aproximar-se, mas se os olhos o não estavam enganando, ela vinha muito devagar, como acontece às vezes nos sonhos, a túnica movia-se, ondulava, modelando ao andar o balanço rítmico das coxas, e os cabelos pretos da mulher, soltos, dançavam-lhe sobre os ombros como o vento faz às espigas da seara. Não havia dúvida, a túnica, mesmo para um leigo, era de prostituta, o corpo de bailarina, o riso de mulher leviana (SARAMAGO, 2000: 279).

8 "Iahweh Deus disse à mulher: 'Que fizeste?' E a mulher respondeu: 'A serpente me seduziu e eu comi'." (BÍBLIA, 2015: 37).

9 "Desde os longínquos séculos medievais, a Literatura Portuguesa contém inúmeros exemplos de figuração da mulher demoníaca, associada ao pecado e à perdição, com ecos na escrita contemporânea. De fato, o mais curioso é verificarmos que esta representação do feminino se prolonga até à atualidade. Por exemplo, em duas criações de José Saramago [Blimunda e Madalena], escritor em cujos universos romanescos somos confrontados com imagens inesperadamente superlativas de figuras femininas dotadas de superioridade $\mathrm{e}$ de sabedoria, e por consequência, parodicamente distanciadas de reconhecidas matrizes culturais" (MARTINS, 2017: 196).

10 A sibilia predizia a sorte; a feiticeira, o fato. É a grande, a verdadeira diferença. Ela evoca, conjura, opera, por assim dizer, o destino. Não é a antiga Cassandra que via tão bem o futuro, o deplorava, o aguardava. A feiticeira acredita neste futuro. Mais que Circe, mais que Medeia, ela tem à mão a varinha da virtude natural, e por guia e irmã a Natureza. Ela já tem as feições do Prometeu modero. Nela começa a indústria, sobretudo a indústria soberana que cura, que conforta o homem" (MICHELET, 1974: 6).

11 Recordem-se as palavras do narrador de Memorial do Convento, imediatamente após a real relação sexual entre rei e rainha de Portugal: "É D. Maria Ana quem puxa o cordão da sineta, entram de um lado os camaristas do rei, do outro as damas, pairam cheiros diversos na atmosfera pesada, um deles que facilmente identificam, que sem o que a isto cheira não são possíveis milagres como o que desta vez se espera, porque a outra, e tão falada, incorpórea fecundação, foi uma vez sem exemplo, só para que se ficasse a saber que Deus, quando quer, não precisa de homens, embora não possa dispensar-se de mulheres" (SARAMAGO, 1989: 17). 
Tempos depois, já unido maritalmente a Madalena, Cristo faz nova visita à própria família em Nazaré - ocasião para novos atritos com a mãe. De volta à vida regular com sua esposa, ele convive com João, Pedro, Simão, Tiago, Judas e outros apóstolos. Opera milagres - cura doenças, aumenta a fartura de comes e bebes - e passa a viver como pescador, até o dia em que ele e seus crescentes seguidores começam a semear a palavra de Deus.

O discurso em nome do Pai chegaria aos territórios mais distantes, graças ao seu intermédio terreno e, claro, aos calçados desgastados pelo uso. A simplicidade de suas vestes projeta no discurso do filho escolhido o ethos de orador humilde, trabalhador e infenso à vantagem material, no que se distancia da própria igreja dourada, séculos depois.

\section{Imago}

Sintetizada no final da Idade Média, a figura de Satã logrou alguns feitos profícuos que favoreceram a manutenção e o incremento de poder da Igreja Católica, dentre os quais a "inculpação individual” (BASCHET, 1990) - atrelada ao fortalecimento do poder do Estado, favorecido pela crença no julgamento final. A ideia generalizada de Bem versus Mal irradia-se na reunião das forças políticas e católicas, em seu combate às trevas e aos crimes contra o poder majestático. Robert Muchembled observa que:

A invenção do diabo e do inferno com base em um modelo radicalmente original não é simplesmente um fenômeno religioso de grande importância. Ela marca o nascimento de uma concepção unificadora, compartilhada pelo papado e pelos grandes reinos, visando, cada um, a monopolizar os benefícios em proveito próprio. O sistema de pensamento que elabora uma imagem triunfante de Satã assinala um enorme impulso de vitalidade no Ocidente (2001: 18).

No contexto romanesco, Diabo é transposto em desacordo com o imaginário popular. Explica-se: no Evangelho de Saramago, Deus responde por ações (próprias e alheias) contraditórias, enquanto Diabo revela-se uma entidade menos violenta e mais coerente que o Senhor. Como reparou Salma Ferraz, trata-se de um "evangelho humanista 
que é construído por um evangelista que relê, pelo lado demoníaco, episódios bíblicos dificilmente questionados, instaurando, assim um mundo às avessas" (FERRAZ, 2012ª. 150 - grifos da autora).

O problema é que as palavras quase nunca estão sós. No romance, a associação entre literatura e pintura permite questionar o senso comum. A antiga analogia entre pintura e poesia, entre os greco-latinos, é retomada com vigor pela igreja católica, no final da Idade Média. De um lado, a fixação de lugares determinados (os nove círculos) no Inferno de Dante; de outro, a crescente representação do trono de Satã em gravuras, monumentos e esculturas. Imagem e verbo a sugerir o poderio acumulado do Inferno e a reforçar a culpabilidade dos homens, representados em personagens supliciadas:

Entre os anos de 1330-1340, Buonamico Buffamalco pinta, sobre os muros do cemitério monumental de Pisa, um ciclo de afrescos associando o Julgamento final, o Inferno, o Triunfo da Morte e a Tebaida $^{12}$. [...] O aprimoramento dos suplícios atinge, aqui, o degrau de maturação constatada nas visões do século XII: o corpus de castigos se expande, os modos de ataque ao corpo diversificam-se, incluindo em particular as formas de ruptura da integridade física (BASCHET, 1990: $5)$.

José Saramago certamente conhecia a tradição horaciana do ut pictura poesis. Ela já havia sido sugerida e romanceada em seu Manual de Pintura e Caligrafia, publicado em 1977. Não é à toa que, no Evangelho, o escritor abre e encerra o romance centralizado na crucificação de Jesus Cristo. Marlise Vaz Bridi propôs uma chave de leitura produtiva, ao defender que a imagem representada no primeiro capítulo do Evangelho seria a famosa tela de Dürer, Crucificação ${ }^{13}$, produzida em 1508:

No processo de tranposição da arte silenciosa e estática da gravura, feita por imagens, para a palavra literária, móvel e ambígua, vão-se incorporando novos significados aos convencionais que, tradicionalmente, se vinculam a cada um desses elementos presentes na vasta iconografia acerca do tema através de comentários que, se

12 Religião cultivada em Tebas, no Antigo Egito.

13 Uma reprodução da gravura pode ser vista neste link: https://upload.wikimedia.org/wikipedia/commons/a/a3/Albrecht_D\%C3\%BCrer_-

_The_Crucifixion_\%28NGA_1943.3.3496\%29.jpg - Acesso em 17 de julho de 2018. 
efetivamente partem do estabelecido, vão passo a passo desconstruindo a visão sedimentada, para construir outra em seu lugar (BRIDI, 1998: 116).

Por um lado, o escritor colocava em questão a poderosa instituição sediada no Vaticano, ao sugerir que tanto as artes da imagem, quanto a literatura seriam capazes de representar pessoas e cenas (in)verossímeis, obedecendo aos artifícios e regras a elas inerentes, mediante interesses escusos. Por outro, o romancista combatia o poderoso senso comum - acumulado ao longo de séculos, que se respaldava no discurso folclórico, na institucionalização do pecado ${ }^{14}$, no rigor da legislação terrena -, que tende a aproximar o julgamento temporal do espiritual.

Quando uma visão, no caso, a do Autor, coloca-se como questionadora da convencional, pressupõe, como método, que todas as convenções serão palmilhadas (como está sendo a própria gravura de Dürer) em ponto maior. Assim serão as figuras dos Evangelhos (em todas as suas versões), as práticas guardadas pela tradição (judaica, por exemplo), os dados da história e assim por diante que serão encenadas e confrontadas (BRIDI, 1998: 121)

É sugestivo que o Evangelho reserve reduzido número de páginas aos sofrimentos e à morte de Jesus Cristo. A Saramago não interessava enfatizar a imputação da pena, pelo Procurador Pilatos, tampouco a severidade dos castigos infligidos pelos soldados romanos ao filho de Deus. Emoldurado pela gravura de Dürer (no primeiro capítulo) e pela descrição ordinária da morte física (no capítulo final), o romance sugere que a morte de Cristo é terrena e participava, desde sempre, dos grandiosos planos do Senhor.

Concebido histórica e materialmente, o Evangelho de Saramago não reserva lugar para a especulação metafísica. Não há espaço ou tempo para a Ressurreição, nem vida após a morte. O que existe é a disputa pelos poderes de Deus e Diabo, aplicados desde muito antes de Cristo, ao plano terreno.

A questão não é ociosa. Antes de as artes sacras darem novas formas a Diabo, a partir do século XIV, um dos impasses discutidos pelos teólogos medievais estava no

14 “O pecado do Diabo tem conteúdo e qualidade. O conteúdo é a escolha dele de rejeitar o livre presente de Deus de graça sobrenatural para procurar felicidade natural. Era impossível que o Diabo, um dos anjos mais altos, devesse acreditar que pudesse se igualar a Deus de fato" (RUSSEL, 2003: 193). 
caráter impalpável e fugaz da alma e a incoerência de aprisioná-la em lugares supostamente materiais, como o Inferno ou o Céu:

[A partir do século XII], a única questão delicada concerne à sorte das almas entre a morte individual e o Julgamento: poderão elas ir diretamente para os lugares materiais, que são o inferno e o paraíso, ou, considerando que um ser espiritual não pode ser retido em um lugar material e, menos ainda, atormentado por um fogo corporal, devemos crer que elas aguardam pelo Julgamento em lugares provisórios, mais em acordo com a sua natureza? (BASCHET, 1990: 4).

História como versão dos fatos. Contraposição aos dogmas, por intermédio do discurso lógico. A própria igreja reconhece a importância dos evangelhos apócrifos, como documentos capazes de complementar lacunas dos livros considerados canônicos, como declarou o filólogo Luigi Moraldi:

[...] não era igual em toda parte a relação entre Cristo e o mundo reunido, porque os termos eram considerados em perspectivas diferentes. Incluíam também certa variedade de expressões da fé, da doutrina e da vida comunitária que inicialmente não era considerada como excludente da Igreja. Mas à medida que se apertavam os vínculos da unidade e que se impunham os livros canônicos, a literatura apócrifa foi marginalizada e se tornou, conscientemente ou não, cada vez mais tendenciosa (2016: 27-8)

Alguns dirão que Saramago era um iconoclasta e inimigo da fé (como o declarou a própria igreja, no dia de sua morte ${ }^{15}$ ); outros lembrarão que estamos no âmbito da ficção: a ironia do narrador onisciente ${ }^{16}$ e o espírito contestatório das personagens são uma representação mais verossímil, já que a ênfase do romance recai mais sobre o feito humano que no poder metafísico, postado acima da terra ou debaixo dela. Leyla PerroneMoisés disse-o em 1992:

15 Publicado no sábado, 19 de junho de 2010 - dia seguinte à morte do escritor -, o artigo "A (presumível) onipotência do narrador", assinado por Claudio Toscani para L'Osservatore Romano, ganhou repercussão mundial.

16 "Ao mesmo tempo em que ressalta a sua onisciência, procura restringir a onisciência divina [...] o narrador, ao referir-se a si próprio, usa a primeira pessoa do plural - nós, justamente a pessoa verbal que, no Velho Testamento, marca o discurso proferido por Deus" (FERRAZ, 2012a: 159). 
Ora, o romancista tem suas razões, que a religião desconhece. O diálogo da fé com a razão é um diálogo de surdos, e portanto uma perda de tempo. Mas aqui a questão é outra. A razão de Saramago - e nisso reside a originalidade de sua obra - não é a razão positiva de Renan e outros, que escreveram uma biografia do homem Jesus, explicando seu papel histórico e desmistificado seus milagres. A razão de Saramago é a da ficção, e esta exige do leitor outro tipo de fé, que não é menos misteriosa e apaixonada que a religiosa"17

O que está em questão é a palavra. Institucional ou folclórica, imagética, empregada politicamente pelos reinos, a justificar a soberania do trono e a posição humilde (e não contestadora) dos súditos. A crença em Diabo (contraparte de Deus) envolve a articulação entre a representação imagética de Satã, os estudos em demonologia realizados em mosteiros, abadias e bibliotecas de acesso restrito, e a terminologia em versão simplificada, ministrada publicamente ao maior auditório possível.

Para relativizar a veracidade do verbo de máximo alcance, o escritor recorre a uma epígrafe extraída do Evangelho de Lucas ("resolvi eu também, depois de tudo ter investigado cuidadosamente desde a origem, expor-tos por escrito e pela ordem"). Como notou Eduardo Calbucci:

Saramago escolhe muito bem esses versículos, tanto para justificar a sua criação ficcional como para "incomodar" certas crenças inabaláveis. Aliás, esse desejo pelo "incômodo", que encontra par no ateísmo do romancista, mais uma vez dialoga com o propósito de desmistificar a História oficial, neste caso sagrada, apresentando uma versão humanizadora dos acontecimentos (1999: 71).

Conceitos como culpa/pecado, julgamento/recompensa, danação/castigo, reforçarão o imaginário tanto o erudito, quanto o popular, ao longo dos tempos. "Nos tratados morais, as evocações do inferno se simplificam e se concentram na natureza das penas [...] Os exempla ilustram, no seio de uma prática renovada da predicação, o 
desenvolvimento de uma retórica moral eficaz, que joga com todas as figuras possíveis do princípio de inversão ${ }^{18 "}$ (BASCHET, 1990: 4 - grifo do autor).

A abordagem do Evangelho e da obra saramaguiana, em geral, envolve discutir a linguagem empregada por seus narradores e personagens. Para demonstrar a insuficiência de argumentos e o caráter irrefletido dos lugares comuns - sob pena de serem reproduzidos inclusive por alguns dentre seus leitores -, há que se deslocar a pintura para o presente e transferir a desconfiança de nosso tempo para o passado, seja ele mítico, místico ou cronológico: “Trata-se da sacralização (sem sacralidade institucional) da vida comum. Tal procedimento, visto como paródico da visão estabelecida, não tem, no entanto, qualquer componente de comicidade ou participação no tom baixo ou menor, é mesmo superiormente elevado em sua sugestão" (BRIDI, 1998: 129).

\section{Verbum}

A palavra concentra e revela poder. Especialmente se vier acompanhada de ações lenitivas e práticas miraculosas. Aos poucos, o verbo divino não só persuade legiões inteiras da Judeia e da Galileia. Sob jurisdição do Império Romano, concentrado nas mãos de Herodes, o que se afirmava como puro amor e boa vontade passa a ser interpretado como desafio ao poder do Rei e a governança temporal de seus domínios: “[...] Deus, que com prontidão expedita e mão pesada se pagara do erro de David, parece agora que assiste alheado à vexação exercida por Roma sobre os seus filhos mais dilectos e, suprema perplexidade, mostra-se indiferente ao desacato cometido contra o seu nome e poder" (SARAMAGO, 2000: 139).

Para argumentar em nome de Deus, Jesus contaria com dois expedientes: reproduzir a máxima "Arrependei-vos", e, como a injunção poderia não surtir o efeito persuasório desejado, haveria que "deixar as pessoas inquietas, duvidosas, levá-las a pensar que se não conseguem compreender, a culpa é só delas, Devo-lhes contar histórias, Sim, histórias, parábolas, exemplos morais, mesmo que tenhas de torcer um bocadinho a lei” (SARAMAGO, 2000: 376). Após uma ceia habitual, em que todos os apóstolos e

18 Jêróme Baschet (1990) chama a atenção para uma das fórmulas apregoadas dentro e fora da Igreja, desde o final da Idade Média: "gozo em vida; sofrimento após a morte; pena em vida, gozo após a morte". 
suas companheiras estavam reunidos ao Messias, Jesus Cristo é identificado por soldados romanos e levado em presença do Procurador Pôncio Pilatos ${ }^{19}$ :

Que dizes tu que és, perguntou o procurador, Digo o que sou, o rei dos Judeus, E que é que pretende o rei dos Judeus que tu dizes ser, Tudo o que é próprio de um rei, Por exemplo, Governar o seu povo e protegêlo, Protegê-lo de quê, De tudo quanto esteja contra ele, Protegê-lo de quem, De todos quantos contra ele estejam, Se bem compreendo, protegê-lo-ias de Roma, Compreendeste bem, E para o protegeres, atacaria os romanos, Não há outra maneira, E expulsar-nos-ias destas terras, Uma coisa leva à outra, evidentemente, Portanto, és inimigo de César, Sou o rei dos Judeus (SARAMAGO, 2000: 442).

Na cruz romana, o filho de Deus teme a própria sorte e dirige imprecações ao Pai celestial: "Homens, perdoai-lhe, porque ele não sabe o que fez" (SARAMAGO, 2000: 444). Dito dessa forma, a cena final ultrapassa a moldura de Dürer. A gravura, que havia inspirado o primeiro capítulo do romance, não só foi dissecada e reinterpretada; na cena final, o escritor remove a moldura mística e benevolente da arte, como se a representação romanesca fosse mais realista que a imagem de quase cinco séculos atrás. Para Marlise Vaz Bridi:

[...] poder-se-ia dizer que $O$ Evangelho Segundo Jesus Cristo é, afinal, a gravura de Dürer posta em movimento e, tendo adquirido vida própria, toma rumos inusitados, movendo-se por forças de tal modo humanas que se afasta do sedimento religioso enrijecido pela tradição e, por isso, enfraquecido em sua dimensão sagrada (BRIDI, 1998: 118).

Convenhamos. Desde o começo, Diabo conta com um poderoso aliado: o narrador, que, aderente à perspectiva subterrânea, reforça as razões daquele que se apresenta como mendigo, pastor, anjo: legião. Como notou Carla Carvalho Alves, a respeito de História do Cerco de Lisboa, há uma "afinidade apresentada, ao longo [daquele] romance, entre a voz do narrador e a do protagonista” (ALVES, 2017: 137).

19 “Ora, ele [Jesus] se encontra em um julgamento, isto é, no lugar mais adequado para ser provada a verdade de seu testemunho. No entanto, não é o testemunho em si que é enigmático e árduo, mas a verdade da qual deve dar testemunho, isto é, o fato paradoxal de que ele tem um reino, mas um reino que não é 'daqui'." (AGAMBEN, 2014: 60). 
Sob essa perspectiva, outra forte aliada de Demônio será Madalena ${ }^{20}$, em sua postura de mulher madura e reflexiva. Na forma como é retratada, a esposa de Cristo é o espelho invertido de Maria de Nazaré, a mãe. Como percebeu José Cândido de Oliveira Martins, "Estigmatizada durante tanto tempo, como personificação da luxúria e do pecado, a conhecida meretriz é redimida e acarinha pela voz narrativa de Saramago" (MARTINS, 2017: 196).

Ao longo das páginas, o narrador interpõe comentários, com vistas a reiterar os argumentos de Pastor e os questionamentos de Jesus. Dentre suas intervenções, está a denúncia da postura covarde e egoísta de José, que sequer tentou poupar a morte das outras vinte e cinco crianças - em idade, feição e tamanho de Cristo - para assegurar a sobrevida de seu filho material e futuro Messias. A postura sorrateira de José (que testemunhara o diálogo entre os soldados romanos) guarda coerência com os caminhos misteriosos e brutais por onde passava a palavra de Deus:

Um anjo realmente merecedor deste nome até podia ter poupado o pobre José a estas agonias, basta que aparecesse em sonho aos pais dos meninos de Belém, dizendo a cada um, Levanta-te, toma o menino e sua mãe, foge para o Egipto e fica lá até que eu te avise, pois Herodes procurará o menino para o matar, e desta maneira salvavam-se os meninos todos (SARAMAGO, 2000: 126).

Mais dona de si do que Jesus Cristo era de si próprio, Maria Madalena colabora nas indagações sobre os desígnios do Senhor. É sintomático que a sua voz se misture às reflexões do narrador, como se ela estivesse a reproduzir, em diferente escala, o uníssono reverberado pelo próprio leitor, postado do lado de fora do livro.

Sentada na pedra, à espera de que Jesus volte da pesca, Maria de Magdala pensa em Maria de Nazaré. Até este dia em que estamos, a mãe de Jesus, para ela, fora só isso, mãe de Jesus, agora sabe, porque depois o perguntou, que o seu nome também é Maria, coincidência, em

20 De acordo com Salma Ferraz, "Para compor a magistral Madalena, o autor juntou detalhes da vida e Maria/pecadora, irmã de Lázaro, com informações sobre Maria Madalena, retiradas do Evangelho Apócrifo Segundo Felipe, que informa que Jesus amava mais a Madalena do que a todos os outros discípulos. Também utilizou informações do Evangelho de Maria Madalena, que apresenta Maria Madalena pregando [...] Além das informações dos apócrifos, o autor acrescentou a amizade da Madalena bíblica por Jesus, pois foi a ela que ele apareceu após a sua ressurreição" (FERRAZ, 2012b: 217). 
si mesma, de mínima importância, uma vez que são muitas as Marias na terra, e mais hão de vir a ser se a moda pega, mas nós aventurar-nosíamos a supor que exista um sentimento de mais próxima fraternidade entre os que levam nomes iguais, é como imaginamos que se sentirá José quando se lembra do outro José que foi seu pai, não o filho, mas irmão, o problema de Deus é esse, ninguém tem o nome que ele tem (SARAMAGO, 2000: 330).

Vilém Flusser relacionou uma série de categorias que opõem Deus e Diabo. Deus seria atemporal, inorgânico, menos divertido e respeitador da lei que ele mesmo criou. Da outra parte, Satã introduz a noção de tempo, valoriza o mundo material, faz da risada um modo mais ameno de ser e age, por assim dizer, de modo subversivo. Seja como for, a prevenção contra o Demônio nasce de pseudossabedorias:

Essa sabedoria ensina que o diabo recorre aos 'sete pecados capitais' para seduzir e aniquilar nossas almas. É evidente que a Igreja, em sua propagada antidiabólica, recorre a nomenclaturas um tanto tendenciosas ao denunciar esses pecados. [...] No fundo são, no entanto, inócuos, esses termos arcaicos, e facilmente substituíveis por termos neutros e modernos. É o que proponho. Soberba é consciência de si mesmo. Avareza é economia. Luxúria é instinto (ou afirmação da vida). Gula é melhora do standard de vida. Inveja é luta pela justiça social e liberdade política. Ira é recusa a aceitar as limitações impostas à vontade humana; portanto, é dignidade. Tristeza ou preguiça é o estágio alcançado pela meditação calma da filosofia (FLUSSER, 2008: 25).

Tão grande quanto o poder de Deus era a inconsistência de seus argumentos. Afinal, pelo menos desde os anos mil, setores eruditos da igreja cristã cogitavam meios de solidificar a irmandade, a ser veiculada pelos fiéis. No final da Idade Média, o imaginário popular passou a pensar diabolicamente, à proporção em que Demônio passou a ser representado por meio das artes (esculturas em túmulos, gravuras etc.): “Antes de a arte romana e as cidades adquirirem maior poder, Lúcifer não tinha canais de transmissão para invadir toda a sociedade. A ciência do demônio, a demonologia, era ainda uma especialidade teológica restrita" (MUCHEMBLED, 2001: 22). 
Ao escrever $O$ Evangelho Segundo Jesus Cristo, José Saramago contrapôs-se radicalmente ao senso comum, reproduzido desde a virada para a Era Moderna: "Lúcifer cresce no momento mesmo em que a Europa procura maior coerência religiosa e inventa novos sistemas políticos, preludiando o movimento que vai projetá-la para fora de si, na conquista do mundo, no século XV" (MUCHEMBLED, 2001: 31).

O poder da palavra, a punir os modos e a alargar as bocas que julgam, acumulava as falas de homens eruditos da igreja que, ao longo de séculos, cristalizaram um conceito mais coerente do mal, personificando-o em uma só figura. A sedimentação do Mal permitiu aos reis e demais entendidos justificar a severidade dos castigos, praticados no plano temporal, em nome de Deus. ${ }^{21}$

Os tratados de Bartolomeo e de Cavalca, os sermões de Giordano ilustram uma intensa reflexão sobre o pecado, sobre a confissão e sobretudo sobre as condições da eficácia do discurso moral: como "fazer crer" aqueles que vivem na despreocupação? Como tornar mais imperioso o recurso à confissão? Ora, os aspectos mais inovadores da obra de Buffamalco parecem se inscrever no prolongamento dessas preocupações. Os afrescos ilustram a mesma inquietude na difusão e vulgarização da cultura religiosa, testemunham o mesmo esforço de aperfeiçoamento das técnicas de persuasão e de memorização. A multiplicação de inscrições, endereçadas ao espectador, visa a desenvolver a consciência de um eu pecador, enquanto que a diversificação das categorias penais permite cobrir melhor o campo das faltas, para melhor capturar cada fiel, convidando-o a se sentir visado pessoalmente pela ameaça da danação (BASCHET, 1990: 7).

Da perspectiva cultural, a religião católica harmonizava diversas fontes da sabedoria oral, para dar conta dos folclores e formas com que Ele era evocado e denominado. De modo análogo ao que prescreve São João, passou-se a resgatar a afirmação do Apocalipse de que o Diabo tivesse mil nomes e, portanto, mil faces.

21 "A partir do século XIV, a detalhada evocação dos suplícios infernais dá o exemplo de uma justiça desejada por Deus, implacável, sem apelo, em oposição a uma prática terrestre muitas vezes ineficaz. Ela, lenta e insidiosamente, habitua as populações a pensar que a marca mesma da soberania reside no poder da espada punitiva. Abre-se, assim, pouco a pouco, o caminho que leva a um Estado de justiça mais severo, a um rei capaz de manejar um arsenal de suplícios adequados, em nome de Deus" (MUCHEMBLED, 2001: $35-6)$. 
No romance, as metamorfoses de Diabo não só reproduzem o ideário de que Ele fosse criatura pouco confiável. Instaurador da consciência temporal, as várias formas assumidas pelo Demônio permitem-no corromper o discurso oficial das Escrituras. Ele teria assumido um dos disfarces de Gabriel, ao falar com Maria? Seria ele uma das faces de Deus?

Um crédito ao Senhor das Trevas. Nem Diabo era tão altivo a ponto de sufocar o pedido para reingressar no céu; tampouco Deus foi capaz de perdoá-lo; nem Jesus fora tão magnânimo, a ponto de ansiar pela crucificação - sob os olhos de Marias - a contabilizar, debaixo de pregos e espinhos, o saldo (quiçá positivo) da fé católica. Consciente de que teria que esperar seiscentos anos pela melhor acolhida de seu nome e exemplo, a sua morte corresponde ao sacrifício do cordeiro inocente, em benefício do poder do nome, da expansão territorial e do alargamento da fé.

O Evangelho de José Saramago é quase um tratado de oratória antimetafísica. Fornece numerosos exemplos de contestação à palavra, por definição morta, dos dogmas; mas rediviva, graças aos interesses do clero e do poder secular. À medida que o romance avança, Jesus Cristo percebe que o seu destino estava na mente de Deus e que as palavras advindas da nuvem e do nevoeiro não faziam total sentido.

O diálogo, transcorrido no meio do mar (curso, discurso, caminho?) também carrega a simbologia da água - ambiente localizado entre a terra e o céu. Espécie de purgatório expresso: não-lugar temporário reservado especialmente para a remissão prévia de Cristo, dias antes de sofrer o castigo máximo pelos homens mais violentos do planeta.

Como testemunha do debate (por sinal, brando) entre Deus e Diabo ${ }^{22}$, Cristo estava situado entre dois oradores tão eloquentes e polidos, que de súbito, compreendeu a insólita reunião no barco, em meio à névoa e ao discurso enérgico, mas comportado, de ambos os Pais:

\footnotetext{
Percebo agora por que está aqui o Diabo, se a tua autoridade vier a alargar-se a mais gente e a mais países, também o poder dele sobre os homens se alargará, pois os teus limites são os limites dele, nem um passo mais, nem um passo menos, Tens toda a razão, meu filho, alegrome com a tua perspicácia, e a prova disso é que tem-la tu no facto, em
}

22 “[Diabo] não é um enganador do homem, nem um fanático inimigo de Deus, mas, às vezes, um parceiro dele, embora extremamente moderado e menos sentimental" (FERRAZ, 2012b: 124). 
que nunca se repara, de os demónios de uma religião não poderem ter qualquer acção noutra religião (SARAMAGO, 2000: 371). ${ }^{23}$

A rigor, $O$ Evangelho Segundo Jesus Cristo não poderia ser classificado como romance histórico - denominação que incomodava o próprio escritor. Trata-se de uma narrativa que se pretende sacrílega, a versar sobre matéria mítica. O romance é figurado em um tempo e lugar mítico quebrado, desordenado pelas constantes intervenções do narrador, que relembra a todo instante que o seu Evangelho não é canônico e desafia o teor dos chamados documentos apócrifos.

O questionamento, promovido pela literatura, é duplo: ficção contemporânea a partir da ficção mais antiga (e relativamente estável) de que se tem notícia. O romance pretende lograr maior relevância que o dogma; a humanização é mais coerente que a previdência; a narrativa seria um dentre os discursos possíveis. Sob essa ótica, o Evangelho Segundo Jesus Cristo merece ser lido como parte de um projeto saramaguiano maior:

O caráter irracional, fantástico ou contraditório, dos acontecimentos assim ficcionalizados constrói um efeito de leitura dominado por um operador de ficção que se funda na noção de incredulidade, já que se pratica uma conversão do plano da ficção (plano em que se aceita ser crédulo em nome do postulado que erige os mundos possíveis), sendo esse plano ficcional a própria reconstituição de um real reproduzido tanto como gesto ficcional por excelência que se articula em torno da inverossimilhança, abrindo deste modo as vias do modo feérico (a máquina voadora), do modo fantástico (a Península Ibérica convertida em jangada de pedra) e do modo paródico (as alterações a que se submete a vida de Cristo) (SEIXO, 1999: 84).

Seria $O$ Evangelho Segundo Jesus Cristo um ato de rebeldia em forma de romance apócrifo que mirasse tornar-se exemplar? Por assim dizer, romance canonizável? Talvez seja mais adequado considerá-lo como obra de contestação ao dogmatismo, ao senso

23 “Aos que acreditavam poder usar de subterfúgios com o diabo e, portanto, com Deus, a nova imagem infernal explica que eles não conseguirão escapar da sua sorte. A ameaça se torna mais dramática, obrigando fiéis culpabilizados a tentar dela eximir-se por meio da confissão, da devoção. A acentuação do medo do inferno e do diabo tem, provavelmente, por resultado um aumento do poder simbólico da Igreja sobre os cristãos mais atingidos por estas mensagens" (MUCHEMBLED, 2001: 36). 
comum e à falsa moral. Sabedor dos usos e abusos da palavra, quando reproduzida sem maior reflexão, o romancista elege uma das narrativas mais conhecidas do planeta, para fazer dela matéria ficcional. Supondo que a palavra de Deus seja considerada inquestionável, por parte dos adeptos, nada impede que ela molde a composição romanesca.

Vale lembrar que, formalmente, o discurso do senso comum se afasta do Diabo (antepondo o artigo determinado antes de seu nome); por sua vez, as palavras Deus e Jesus não admitem o artigo. Talvez porque Estes seriam figuras do Bem - entidades maiores, melhores e inapreensíveis. O fenômeno linguístico não deixa de ser curioso: aquele que se define como "legião" 24 precisa ser indicado e restringido nominalmente pela categoria gramatical. Como se vê, a representação de Deus e Diabo começa por um problema de sintaxe.

\section{Fontes}

SARAMAGO, José (1989). Memorial do Convento. $8^{\mathrm{a}}$ ed. Rio de Janeiro: Bertrand. (1999). Cadernos de Lanzarote II. São Paulo: Companhia das Letras. (2000). O Evangelho Segundo Jesus Cristo. $25^{\mathrm{a}}$ ed. Lisboa: Caminho.

\section{Referências Bibliográficas}

AGAMBEN, Giorgio (2014). Pilatos e Jesus. Trad. Silvana de Gasperi; Patrícia Peterle. São Paulo: Boitempo: Florianópolis: Editora da UFSC.

ALVES, Carla Carvalho (2017). Marginalidade e Alteridade nas Personagens de José Saramago e Mário de Carvalho. In: PAVANELO, Luciane Marie et al. Marginalidade Ferminina: a Mulher na Literatura e na Cultura Brasileira e Portuguesa. Montes Claros (MG): Editora Unimontes, 2017.

BALEIRO, Zeca (2013). Heavy metal do Senhor. In: Por onde andará Stephen Fry? [CD]. MZA Records.

BARCELLOS, José Carlos (2003). "Entre Pai e Filho: o cristianismo dilacerado em $O$ Evangelho segundo Jesus Cristo, de José Saramago". In: CANIATO, Benilde Justo

\footnotetext{
24 "Chegaram do outro lado do mar, à região dos gerasenos. Logo que Jesus desceu do barco, caminhou ao seu encontro, vindo dos túmulos, um homem possuído por um espírito impuro: habitava no meio doas tumbas e ninguém podia dominá-lo, nem mesmo com correntes. [...] Ao ver Jesus, de longe, correu e prostrou-se diante dele, clamando em voz alta: 'Que queres de mim, Jesus, filho do Deus altíssimo? Conjuro-te por Deus que não me atormentes!' Com efeito, Jesus disse: 'Sai deste homem, espírito impuro!' E perguntou-lhe: 'Qual é o teu nome?' Respondeu: 'Legião é meu nome, porque somos muitos'.” (BÍBLIA, 2015: 1765-6).
} 
Caniato; GUIMARÃES, Elisa. (Orgs.). Linhas e entrelinhas: homenagem a Nelly Novaes Coelho. São Paulo: Editora Casemiro, pp. 149-153.

BASCHET, Jérôme (2017). "La Justice de l'au-delà. Les représentations de L'enfer em France et en Italie (XII-XVème siècle)". Paris: Les Cahiers du Centre de Recherches Historiques (1990). Disponível em: http://ccrh.revues.org/2886 Acesso em 17 de julho de 2018.

BASTAZIN, Vera (2006). Mito e poética na literatura contemporânea: um estudo sobre José Saramago. Cotia: Ateliê.

BÍBLIA de Jerusalém (2015). 10 $10^{\mathrm{a}}$ reimp. Vários Tradutores. São Paulo: Paulus.

BRIDI, Marlise Vaz (1998). O Evangelho de Saramago: a Paixão de Cristo em Perspectiva. In: LOPONDO, Lilian (Org.). Saramago Segundo Terceiros. São Paulo: Humanitas, pp. 111-130.

CALBUCCI, Eduardo (1999). Saramago: Roteiro para os Romances. Cotia: Ateliê.

FERRAZ, Salma (2012a). As faces de Deus na obra de um Ateu. 2a ed. Blumenau: Edifurb.

(2012b). Dicionário de personagens da obra de José Saramago. Blumenau: Edifurb.

FLUSSER, Vilém (2008). A História do diabo. $3^{\mathrm{a}}$ ed. São Paulo: Annablume.

MARTINS, José Candido de Oliveira (2017). A Mulher e o Diabólico: Representações Culturais e Literárias de um Imaginário Intemporal. In: PAVANELO, Luciane Marie et al. Marginalidade Ferminina: a Mulher na Literatura e na Cultura Brasileira e Portuguesa. Montes Claros (MG): Editora Unimontes, pp. 189-204.

MICHELET, Jules (1974). A Feiticeira. Tradução de Ronaldo Werneck. São Paulo: Círculo do Livro.

MORALDI, Luigi (2016). Evangelhos Apócrifos. $8^{a}$ reimp. Tradução de Benôni Lemos; Patrizia Colina Bastianetto. São Paulo: Paulus.

MUCHEMBLED, Robert (2001). Uma História do Diabo (Séculos XII - XX). Tradução de Maria Helena Kühner. Rio de Janeiro: Bom Texto.

PERRONE-MOISÉS, Leyla (2000). Saramago, uma questão de fé. In: Inútil Poesia e Outros Ensaios Breves. São Paulo: Companhia das Letras, pp. 175-181.

RUSSEL, Jeffrey Burton (2003). Lúcifer - O Diabo na Idade Média. Tradução de Jorge Luiz Serpa de Oliveira. São Paulo: Madras.

SARAMAGO despede-se para sempre de Lanzarote, ilha na qual viveu e morreu. Disponível em: <http://g1.globo.com/pop-arte/noticia/2010/06/saramago-despedese-para-sempre-de-lanzarote-ilha-na-qual-viveu-e-morreu.html>. Acesso em: 17 jul. 2018.

SARTRE, Jean-Paul (1973). O Diabo e o Bom Deus. Tradução de Maria Jacintha. São Paulo: Círculo do Livro.

SEGOLIN, Fernando (1999). O evangelho às avessas de Saramago ou o divino demasiado humano ou o Deus que não sabe o que faz. Cad. CESPUC de Pesq., n. 4. Belo Horizonte, pp. 12-20.

SEIXO, Maria Alzira (1999). Lugares da ficção em José Saramago. Lisboa: Imprensa Nacional/Casa da Moeda.

SEPÚLVEDA, Torcato (1992). "Sousa Lara corta nome de Saramago". Jornal O Público, 25 de abril, s/p.

Artigo recebido em 17 de julho de 2018.

Aprovado em 25 de maio de 2019. 